\title{
Why China Should Regulate Its Overseas Investors' Environmental Behavior
}

\author{
Ciprian N. Radavoi, Yongmin Bian \\ School of Law, University of International Business and Economics (UIBE), Beijing, China \\ Email: $\underline{\text { radavoi@uibe.edu.cn, bianyongmin@uibe.edu.cn }}$
}

Received 7 January 2014; revised 8 February 2014; accepted 3 March 2014

Copyright (C) 2014 by authors and Scientific Research Publishing Inc.

This work is licensed under the Creative Commons Attribution International License (CC BY). http://creativecommons.org/licenses/by/4.0/

(c) (i) Open Access

\begin{abstract}
In the half-century-old debate on disciplining the overseas behavior of transnational companies in fields like human rights and the environment, emerging economies' potential as capital exporter states is largely ignored: they are usually perceived as the problem, rather than a solution provider. When they take action, usually with the aim of enhancing their reputation globally, they limit it to voluntary codes and recommendations to their overseas investors, like China did during the recent years. This article explores, through an interdisciplinary approach blending public relations, international relations and socio-doctrinal legal analysis, China's negative and affirmative motivations for moving ahead and taking regulatory steps in disciplining its investors' behavior. Practical (reputational) and ethical factors are analyzed, leading to the conclusion that China has strong motivators for taking action in the actual international context. The country's policy makers can put them in balance with the status-quo motivators (mainly, related to economic comparative advantage) and decide accordingly.
\end{abstract}

\section{Keywords}

China's Overseas Investment; Corporate Social Responsibility; Foreign Direct Investment; Environment Protection

\section{Introduction}

In spite of decades-long academic debate on holding Transnational Corporations (TNCs) accountable for human rights infringements, they still largely operate in a vacuum as far as real responsibility is concerned, being bound mostly by self designed codes, or by codes adopted by their organizations or industries, all voluntary and of debatable efficiency. The history of the last decades is the one of failures as far as addressing corporate overseas blameworthy behavior is concerned - the most notable being the two aborted attempts, at the United Nations, to adopt binding norms for corporations_-failures caused by the multitude of political, jurisdictional, geographic, 
conceptual, cultural or institutional variables involved.

In academic journal articles, statistics on how many TNCs are among the 100 world economies (countries and TNCs) are frequently quoted, and the impressive figures of their capital seem to be enough for legitimizing their power on the international stage. There are, however, TNCs whose legitimacy goes beyond money: the ones from the emerging economies (EEs). As long as these home states' cumulated population is nearly half of the world's total, there is some form of legitimacy there. In a way, they are similar to the British, French or Dutch corporations of the XVII century, penetrating remote markets to the benefit of their state. Although they are usually considered part of the international human rights problem in the host countries of their investment, we will argue that on the contrary, substantial reasons point to the EEs as becoming part of the solution.

While reviewing the literature for this article, it occurred to us that the academic and political debate in the 1970s with regard to TNCs' accountability looked pretty much the same as the one we have today. The degree of optimism in the works of the 1970s may look like naïvety today; also, the pressure beneath the debate was nothing like today, since at that time, mother Earth was still not so upset by our pollution, let alone she had to feed only 4 billion. But these differences aside, the preoccupation, the concepts involved, the flaws identified are strikingly similar, leading to one simple question: why, in more than half century, no advancement was seen?

In a stalled debate, evaluating the potential of new developments is essential. One of these developments is the world slightly moving from a bipolar (till the 1990s) towards a unipolar world, and probably a multipolar one in the future, with the new poles selected from the EEs of today. If for now, UN is incapable of adopting the Norms, so the hot potato of enhancing TNCs responsibility stays at state level, EEs are in a better position than any other state to take the appropriate measures and succeed, as home states, where the West failed. They adopted privatization and market economy, but are still heavily regulated, which provides much more opportunity for disciplining their overseas investors, compared to the Western state's situation. And this goes for all investors of that country, not only the SOEs, who are directly controlled and affected by governmental measures; other enterprises as well are inevitably under the effect of the same specific institutional political, economical and cultural environment. The problem is, EEs may have the tools, but do they have the motivation? Why would their governments want to endanger the competitiveness of TNCs by regulating their overseas behaviour-i.e., by doing more than a mere isomorphic adoption of the CSR practices?

The answer is related to their political aspirations. The EEs, defined as countries with a rapid pace of economic development, and with government policies favouring economic liberalization, are not a homogenous and clearly identifiable group (Hoskisson et al., 2000). Among them, however, some-Brazil, Russia, India, China, commonly referred to as the BRICs - coagulated as a group, sharing the belief that their role in the international politics should increase and consequently holding yearly summits starting from 2009, to discuss the common and global challenges. They account for a quarter of the total land surface of the world and 40 of its population, and their GDP combined was a quarter of the world's GDP in 2010 (up from a mere 8\% in 2000). In spite of growth lately slowing down in all and especially in India, and of other difficulties encountered by some of them, BRICs will retain their status at least for this decade (Global Intelligence Alliance, 2011) and they qualify for becoming new poles of power, in the world of tomorrow.

Raw economic and military power alone, however, is not enough, a powerful state needs legitimacy, recognition by others: by "[its] peers in the club, but also by smaller and weaker states willing to accept the legitimacy and authority of those at the top of the international hierarchy” (Hurrell, 2006).

But the pressure on the four BRICs in obtaining this acceptance is not equal. While all display economic, military and political potential to contribute to the production of international order, China is arguably the most prominent and thus the most vulnerable to bad image spread by potential wrongdoing of its investors. Aside from this negative incentive (reputational risk) there are also affirmative ones, opportunities that point to China's interest and ability to step-in decisively in the stalled debate on TNCs' responsibility and accountability.

\section{A Good Voluntary System in China-Why Not Enough?}

In only 6 months (September 2012 to February 2013) the Chinese government modernized its approach to its overseas investors' environmental wrongdoing to a level rivalling the OECD one, but the move went almost unnoticed in the international academia. CSR was introduced in China more than two decades ago (World Economic Forum, 2012), but some recently adopted documents justify the assertion that more recently, China chose a robust, intense and comprehensive approach. These documents are the Guide on Social Responsibility for Chinese International Contractors (GSRCIC 2012), issued by China International Contractors Association in 
September 2012; the Green Credit Guidelines, adopted by China Banking Regulatory Commission in February 2012; and the Guidelines for Environmental Protection in Foreign Investment and Cooperation (GEP 2013), issued jointly in February 2013 by the Ministry of Commerce and Ministry of Environmental Protection.

Why then no word in the international scholarship on this effort? We argue in Chapter 3 that whatever China does in the CSR field, it is seen as the laggard; scholars will keep exploring "the conceptual and practical gap existing between the developed and developing countries in relation to corporate social responsibility (CSR), or the North-South CSR Divide” (Gugler \& Shi, 2009). Therefore, we suggest that China has enough motivation and acceptable (fitting within its policies) options for a step forward: adopting regulatory measures in this field.

Before analyzing China's various incentives for a hypothetical move towards binding regulation of some sort, a word on pragmatism is necessary. We will limit the discussion to TNCs' environmental wrongdoing and subsequent lack of accountability. China has the incentives and potential to come up with solutions to TNCs accountability, but for some reasons that are not the concern of this paper, the words "human rights" do not sound well for its government; and for sure, not civil and political rights. It is common knowledge in the history of human rights' evolution that libertarian states such as US argued that civil and political rights are the only rights immediately justiciable and enforceable, whereas developing states, on the contrary, claimed the prominence of the economic, social and cultural rights: when people struggle to feed themselves, civil and political rights are of little significance. Since this paper deals with China's prospective of improving its overseas investors' behavior, it makes sense to not bring into discussion a sensitive variable-infringement by TNCs of civil and political rights - that will rend the whole construction doomed to failure.

Moreover, when one tries to achieve too many targets at once, he may fail. Maybe the international efforts at the UN to regulate the TNCs behavior and responsibility were just too ambitious, aiming to address too many fields at the same time. This argument is better understood if we think of a parallel with the migration field, where UNHCR decouples the notion of refugees, depending on the cause of populations fleeing their homeland. Environmentally displaced persons are not even called refugees, as using this terminology would undermine the refugee framework under the Geneva Convention (UNCHR, 2008); similarly, we argue that the debate on holding TNCs accountable at the same time for wrongdoings regarding human rights and environmental ones undermines the protection of the latter.

Besides, the voluntary system briefly presented in the beginning of this section clearly confirms the above: with a good set of voluntary and comprehensive rules (the above mentioned GSRCIC 2012) in place, China chose, after only one year, to adopt new Guidelines (the GEP 2013), this time dedicated exclusively to the environment! We see this sudden move as a sign of good faith, as a genuine desire to let them "work" by decoupling them from problematic fields: the previous, all-encompassing rules for example had extensive focus on labor issues, although China did not sign four, out of the eight major international conventions on labor!

Soon after the recent effort to modernizing its voluntary system for improving its overseas investors' behavior, China sent some discrete messages that more binding rules are considered for the future (Hu, 2013). "What" these solutions could be is another discussion; as for our article, it is concerned with "why" questions.

Before moving more in detail do "push" factors, there is a "pull" one that immediately comes to mind: there is an empty seat there, waiting to be taken! Indeed, one can hardly disagree with the words of Shinsato when she says that "wealthy countries, such as the US, are typically in a better position to regulate parent corporations and to impose liability through their court systems" (Shinsato, 2005); but, as the same author notes, developed countries shun this responsibility. As far as environment is concerned, US arguably shifted from being the leader of the multilateral action in the 1970s to 1980s, to passivity and non-participation, see the rejection of the Convention on Biological Diversity (CBD, open for signature in 1992, at the Rio Summit) and the withdrawal from the Kyoto Protocol on climate change in 2001. The United States has shown itself to be concerned more with national economic interests than global environmental threats, leaving the leading role in these matters to the European Union (Falkner, 2005; Keleman \& Vogel, 2010; Kirshner, 2012).

A jurisdictional involution at the home state level seems to take place also in matters of parented TNCs' responsibility and accountability, as suggested by the case of the Alien Tort Claims Act. This provided for a while an avenue for complaints against US-based TNCs, and was even used for claims against TNCs in matters related to environmental destruction - but in 2013, with the famous case Kiobel, the US Supreme Court recently restricted the use of the ATCA to the narrow range of violations the ATCA was intended for in 1789 (CJA, 2013).

Legislative measures of extraterritorial application attempted by US and other Western home countries also failed. CSR Bills were introduced in the Parliaments of US (2000), Australia (2000), United Kingdom (2004) 
and Canada (2009). All were rejected, some in the plenum, some in commissions, some did not even make it to the commissions. The non-judicial remedies imagined by OECD in order to ensure TNCs compliance, the NCPs established in host countries of investments, also proved useless, reinforcing the idea that the Western world is stuck in the voluntary CSR solution, and unable to find more efficient ways to address their responsibility as home countries of the majority of TNCs.

China, the world's second economy, has the opportunity to occupy this empty seat; it has practical (connected to image and reputation) and ethical arguments to be analyzed hereafter.

\section{China and the Interest-Based View}

\subsection{Reputation and the Negative Factors}

Company reputation is "a perceptual representation of its past actions and future prospects that describe its overall appeal to all its key constituents when compared to other leading rivals" (Fombrun, 1996), which turns it into an essential asset- "the most strategic, inimitable and enduring one that a corporation can possess" (Cravens, 2003). If one century ago, reputation risks were mainly connected to the product quality, nowadays, modern themes like environmental concerns pose great threats to company reputation, if not handled well. And not only to corporate reputation: Lopez, Gotsi and Andriopoulos (2011) unveiled the mechanism by which loss of corporate reputation can affect country of origin (COO) image, in certain conditions. The observation that China is particularly vulnerable to its corporation's loss of reputation is the departure point of this section; as for the approach, it is a pragmatic one, inspired by the utilitarian stance the corporations take on CSR. They do it largely because it is good for business, and the world is happy enough with the result to not question the motives; similarly, China could take strong steps towards improving its corporations' environmental behavior because it is good for itself (by reducing the risk of transferring TNCs' reputational loss into country's image damage) and the result would be positive for the whole planet.

For understanding the above mentioned risks and why they are higher for China, we start with a look at TNCs from three different countries-China, Canada and US-investing in mining in Latin America, the destination area of more than half of Chinese FDI in natural resources. All three were involved in environmental wrongdoing and subsequent criticism, but with different impacts on $\mathrm{COO}$ image.

For China, a notable presence in the region is Shougang Group, after the purchase in 1992 of a large Peruvian state-owned mining enterprise. According to many reports available online, the Chinese investment generated problems in many regards, from respecting investment commitments and paying due taxes, to labor and environmental blameworthy behavior (see for example, the study of Kotschwar, 2012) The case was enthusiastically reported in Western media under generalizing titles containing the syntagm "Chinese companies"; for example, on 24 February 2012, Forbes was titling: "Are Chinese Companies in Latin America Paying Attention to Corporate Social Responsibility?” A respected researcher (Cynthia Sanborn of Peru’s Universidad del Pacífico, quoted in Kotschwar, 2012) stated that "China has difficulty regulating what its companies do abroad", and the connection with the China's environmental footprint in Africa, already notorious by that time, was quickly made: in relation to Chinese investments in Latin America, José de Echave, director at Cooper Acción, was asking for prudence because "it's well known that the track record of Chinese companies in Africa, and in China itself, has not been so good in terms of the labor force and the environment". ${ }^{1}$ This quote is just another proof that bad labels are difficult to remove, as at the time of this statement, China had already begun responding the environmental criticism in Africa with positive concrete measures. In spite of this reaction, Chinese involvement in Africa will be for a long time quoted as example of substandard environmental practice.

Moving to Canadian mining companies, there is to be noted that they dominate the market in Latin America and the Caribbean, although their share decreased after the global crisis, from $49 \%$ to $32 \%$ according to Natural Resources Canada, a governmental agency. ${ }^{2}$ The Canadian mining companies have a huge record of wrongdoing in all Latin America, unveiled by major international NGOs, as a Google search will show-examples include Barrick Gold environmental degradation in Ecuador and water pollution in Argentina (Todd \& Weber, 2008), Goldcorp having provoked a huge scandal in Honduras after cyanide leaking (Spring, 2011), the same having been involved in illegal deforestation in Guatemala (Rocio \& Yagenova, 2009), and the list is much longer.

A quick search for environmental wrongdoing in Latin America by US based mining corporations also reveals

1http://www.ft.com/cms/s/0/77666ad0-23f0-11e0-bef0-00144feab49a.html\#axzz298K1dzb6

${ }^{2}$ http://www.nrcan.gc.ca/minerals-metals/business-market/canadian-mineral-exploration/2009/3736 
numerous cases: in Peru, Newmont Mining is involved in the highly controversial Conga gold and copper mine project; Glencore's Colombian subsidiary, Prodeco, came under fire for reportedly disposing of waste illegally (REPRISK, 2010) and the list could go on for pages. What is striking is that in both cases of Canadian and US companies, many protests subsequent to environmental damage have triggered brutal repression and even killings; while violent reaction was reported in case of protests against Chinese TNCs as well, the brutality did not reach such a degree. Moreover, the most publicized case of a Chinese corporation abusing the environment, the one of Shougang, was followed by a quick reaction from the Chinese authorities. According to the same study that reports Shougang's abusive behavior, the subsequent Chinese investment in mining in Peru came with visibly improved environmental standards. Why, then, the general perception is still reticent when it comes to Chinese TNCs and the environment, but no such a thing can be said about US and Canadian based corporations?

While the COO influence on products and corporations' image was extensively researched in the last decades, the opposite relation has only recently been given attention. Downling (2004) seems to be the first who proved that country image can not only affect, but also be affected by the images people hold of its companies, industries and brands. We propose four ways in which this mechanism may work in the case of China, making it more vulnerable than other countries to image damage, in case of its corporations' blameworthy behavior overseas.

\section{- Pre-established perceptions die hard}

A TNC's reputation is shaped by the information the public receives on its behaviors, either through independent mass media or directly from the company. We already noted the tendency of the international media to label any wrongdoing of a Chinese TNC as revealing deeper causes in the home country society. The actual state of facts as far as media reaction to Chinese TNCs wrongdoing needs to be seen in connection with older reports on the fabulous economic ascension of China, which came along with serious environmental devastation at home. Decades of reports on China prioritizing growth over human rights and environment at home inevitably left a deep print in the collective memory, and now the track of poor environmental record at home is deemed as exported to Africa, SE Asia and Latin America, through the overseas investors.

These problems of poor implementation of environmental standards also count for western extractive companies and investors, as shown before, but the main difference is that for Chinese investors, they are thought to reflect weak environmental regulation within China. The policies and institutions set by the Chinese government to tackle the environmental problem after the turn of the century had little chance to improve the perception abroad, regardless of their effectiveness.

It is common knowledge, in Public Relations, that is extremely easy to acquire a bad image, but very hard to break away from it. Psychological theories of perception explain that people are much more ready to accept information consistent with their existing perceptions than information that contradicts them. That is why, for instance, the praiseworthy behavior of Chinese investors in Peru after the Shougang scandals remained largely unnoticed. Moreover, facts inconsistent with the established perception are, even if acknowledged, at least being "attached" some consequences that fit with the initial perception: China's progress at home in dealing with the environment is for example deemed as having pushed the bad corporations moving their operations in the third world, were standards are lower.

The resilience of established perceptions, especially of bad ones, can be also explained in a different perspective: the inter-group perceptions. People tend to use character-based attributions to explain an out-group's undesirable behaviors and use situational attributions to explain the out-group's desirable behaviors (Wang, 2003), so that Shougang blameworthy behavior in Peru would be seen as a reflection of Chinese character, while Chinalco good record would be considered as a consequence of some situational constraints. As for what could count as "character" to explain the wrongdoing-more specifically, (mis)perception of character-money worship in today's China may be the handy explanation for bad behavior of TNC's; indeed, evidence of unethical business behavior along China's transition to a market economy has also been widely reported in the academic literature on management and business ethics (Shafer, Fukukawa, \& Lee, 2007). The development of business ethics and professional morality had not kept pace with market reforms in the PRC, and traditional Confucian notions of commercial ethics are seriously deteriorated as a result of market reforms, one author finds, after interviewing Chinese state officials (Harvey, 1999).

More research among Chinese managers have shown them being less concerned with humanitarianism, and more concerned with self-interest and profit than their Western counterparts (Shafer, 2007); this perception is now widespread in the international public opinion due to insistent media reporting, and what Shougang managers did in Peru is inherently seen as "proof" of this established "truth", reinforcing it by the mechanism of circular 
confirmation—something like "the media was right, things are not well in China in his regard!”. Or, as the Nigerian human rights lawyer Ndubisi Obiorah famously put it: "China exports the capitalism it knows!” (cited in numerous studies and books, for instance Alden, 2007).

- Strong association Country of Origin (COO)_Transnational Corporation (TNC)

If Sinopec or PetroChina, the two giants of oil and gas industry, would someday be involved in environmental wrongdoing, media will probably report on Chinese companies abusing the environment; if Shell, however, would be the author of the blameworthy act, the media will simply report on Shell, without reference to its Dutch registration — as it actually did, during the well-known Nigerian case that led to the killing of the NGO activists. This association is, on one hand, intended by the Chinese corporations going global, through corporate visual identity - the corporate name, logotype or symbol, typography and color, and using the Chinese writing. Chinese corporate communication usually reinforces the linkage created through visual identity, with the result of strong image association between TNC and COO.

On the other hand, the association also comes indirectly from unintended factors, being the result of the low degree of globalism the Chinese TNCs have reached so far. Indeed, by almost all criteria that defines a global corporation-from purely quantifiable measures such as the percentage of sales occurring outside a home market, global market share, and number of foreign affiliates, to subjective constructs such as corporate leadership's attitude towards global operations, management style, geocentric outlook, and cross-cultural integration (Cavusgil, 2004)—Chinese corporations are far from being labeled global. How could it be otherwise when even the ones not own by the state are deeply embedded in the home country policies, reliant on domestic financing, factors of production, management, labor? After all, they were told to go global, not to be global.

Although China has two TNCs in the Top Ten of the world firms according to Global 500, the annual ranking of the largest corporations realized by CNN - the two Chinese oil giants mentioned rank $5^{\text {th }}$ and $6^{\text {th }}$ - this does not make them retain negative image; on the contrary, it adds to the spillover effect on country image, as seen in the next sub-sections. What could help would be the presence of a Chinese brand in the world's top, as strong brands spill the positive image on the COO, but largely retain the negative image in accidental image crises, see again Shell in Nigeria. Unfortunately, although brands like Haier and Lenovo are increasingly known abroad, China did not succeed so far imposing strong global brands.

What adds to the problem is that Chinese corporations seem to qualify for almost all attributes that predict a bad environmental behavior (factors identified by Etzion, 2007). The size of Chinese corporations can be deemed as a hindrance for a flexible approach to environment, their integration of multi-stakeholder perceptions and concerns is seen as low, the R\&D is seen not at the level of their Western competitors, and so on. Moving to the industry level, we can note that Chinese TNCs are most active in sectors seen as "dirty", such as energy, chemical, constructions, automotive. All these fit too well with pre-established perceptions, thus activating the nodes for TNC and COO in the collective memory, reinforcing a negative image relative to environmental performance (Anderson, 1983, on memory encoding and retrieval; Lopez, Gotsi, \& Andriopoulos, 2011, applying Anderson's theory to COO reputation).

- World Systems Theory and the Earth resources

The fact that the Canadian mining companies' wrongdoing in Latin America did not spread so much emotion worldwide like the Chinese TNCs wrongdoing may also have an explanation under the World Systems Theory. Parented by Wallerstein (1974), this theory explains the success of the hegemonic powers through unequal exchange with, and exploitation of peripheral regions and states.

Canada may be a big country, but with no high political aspirations internationally, which is not the case of China. As an ascending economic and political power in the world system, China has increased its consumption of natural resources and its pollution of the local, national and global environment-a path followed by all the major global powers in the last centuries, from the British Empire to the United States. All ascending states, in their time, sourced the planet for additional natural resources for their economic expansion, as their domestic natural resources fell short; this came along with severe local and global environmental consequences. However, China's situation is different, as Mol (2011) underlines:

One of the significant differences that today's major ascending economies encounter and have to face, is that the environmental profile of rapidly expanding economies is currently a major point of global concern. Although concerns were raised in earlier times on the environmental consequences of upcoming global powers, the global debate and fears of China plundering Africa (and other regions) in search for natural resources, and of China's actual and future contribution to climate change... are unprecedented. 
While before, major powers rising were not bothered by public concern on matters like the climate change, loss of biodiversity or resource depletion, nowadays the eyes of the international community are peeled on the slightest move of the ascending powers. Therefore, any single incident involving a Chinese TNC damaging the environment in a less developed country would be automatically credited to China.

- "Cross-cultural" business ethics and the CSR trap

Being the last in the club definitely makes it harder. As shown in the previous chapters, the Western TNCs developed the Corporate Social Responsibility system which, until proving useful for the planet, is extremely useful for themselves. If we look at the debate on China's corporate responsibility, the CSR system reveals another benefit it brings to its creators: it is a great tool to keep the new comers at the doors.

After the destructive capitalism that devastated it territory for decades, China engaged at home in a process of ecological modernization, which, most of the authors agree, is pursued with consistency and determination, in spite of many implementation failures. From practical measures like reforestation, to increased reliance on renewable sources and massive investment in the related $\mathrm{R} \& \mathrm{D}$, and to strong environmental protection rules, things are going in the right direction at home. As for the international arena, Chinese state authorities do not ignore anymore the criticism raised by blameworthy behavior of its TNC; like in the Peru case, founded criticism is followed by strong measures. Similar reaction is documented in Africa, where years of substandard operations and ignoring subsequent criticism were followed by notable improvements lately (Mol, 2011). Moreover, the CSR system was introduced in order to align the Chinese overseas investors to international standards: the SASAC Guidelines for investors, the reporting system, sustainability criteria for credit provision were adopted during the $11^{\text {th }}$ Five Year Plan (2005-2010), let alone the more recent measures already referred to.

Far from being actively hostile to CSR, Chinese companies have embraced it and are showing signs of advancing rapidly through the CSR learning curve. Pegg (2012) brings numerous examples in support to the thesis that Chinese TNCs in oil industry substantially improved their behavior. True, all these measures are voluntarybut so are the praised similar ones adopted by the Western TNCs. However, a perceptible image improvement did not come along. And in our view, no matter how much the Chinese overseas investors will struggle to keep up with the Western TNCs in adopting responsible practice codes, they will always be seen as laggards in this field. CSR is the Western TNCs playing field, and China's achievements will be always downplayed in a polite encouraging way to continue the efforts. Heavily funded studies, results of deep research undertaken by large teams, are regularly published by Western scientific bodies, with the conclusion that China advanced on the sustainability road, but there is still a long way to go to reach the Western standards. If the measures are taken, they may be criticized for not being coherent; if they are coherent, they may not be well implemented; if they are well implemented, they may be not followed by the managers, due to their lack of environmental awareness, etc.

It is surprising to us that the country of the Daoism and Confucianism, the country that first in the world discovered the benefits of blending hard and soft law, ${ }^{3}$ accepts this image-damaging game of teacher and (hardworking but always coming second in his class) student. Every study of this kind, while apparently picturing a country honestly trying to catch-up with the Western standards of environmental protection, actually reinforces the pre-established image of a China unable to deal with the issue and struggling hard to learn from the West. This comes with three benefits for the Western TNCs: first, as long as CSR is adopted in China, it levels off the field, annulling the advantage the Chinese competitors may have had, had they not adopt CSR policies; second, it validates the CSR system as a substitute for the UN norms for corporate responsibility; and third, it gives them a playing field where they will always have one point ahead of the competitor.

CSR is essentially a good thing, and in many aspects effective, mainly as far as reporting is concerned, but also with important educational benefits. However, instead of taking classes of CSR from the Western organizations, China could take the lead and "go beyond CSR". ${ }^{4}$

\subsection{Reputation and the Affirmative Factors}

Still under the approach of China's self-interest leading to universally beneficial action, reputation can be seen in a positive manner. Action taken as a home country disciplining its overseas investors would not only eliminate the above mentioned risks (negative approach), but would build a positive image to last. The dual attitude

\footnotetext{
${ }^{3}$ Confucianism, emphasizing morals and harmony, and Legalism, favoring a bureaucratic fabric of strong rules, intertwined and shaped the modern Chinese legal system.

4“Going beyond the law” is claimed in some CSR codes, such as The Caux Roundtable Principles.
} 
so far of China regarding environment—reluctant in some areas, extremely active in others-leaves room for action, and the political landscape offers opportunities: the sit for the unofficial "world champion of corporate environmental responsibility" is not taken. If China puts its weight and resources in resolving, as home country, the TNCs' accountability vacuum, it could take that sit-similarly to having the Scandinavian countries as leaders in environmental protection, Netherlands as leader in some Human Rights protection or US as the leader in non-proliferation compliance, China could become the leader in corporate environmental responsibility.

Would China sacrifice, for a long term image benefit, the short term advantage of its corporations being allowed more environmental flexibility that the Western competitors? There are two precedent situations (Wang, 2003) when it did sacrifice the queen, only to advance with the pawns that can finally be turned into queens anyway. The first case of this nature was China's signing of the Comprehensive Test Ban Treaty (CTBT) in 1996, in spite of its previous firm position, namely: "no signing if US and Soviet Union do not substantially cut down their nuclear weapons". CTBT puts a number of explicit restrictions on China's nuclear development plan, and from a Chinese point of view, the treaty would freeze China's inferior position vis-à-vis Russia and the US and thus seriously undermine its national security and national power—but still, the treaty was signed in 1996.

The second case was the decision of China to not devalue the Yuan in the aftermath of the Asian Crisis of 1997-1998, in spite of the damaging effects that decision had on the economy. The crisis was spreading and due to the depreciation of the other currencies, Chinese exports were threatened - and still, the Chinese government promised the world that it would uphold the value of its currency because it was the right thing to do for a "responsible great power". Chinese policy analysts explicitly linked these actions to the country's image building on the international stage - a necessary asset given its global expansion (Wang, 2003, citing numerous studies).

Strong regulatory action to improve overseas investors' accountability for environmental wrongdoing, without neglecting the CSR aspects but going beyond them, would be consistent in scope with these past actions.

\subsection{China and the Ethical View}

It would be naïve ignoring the self-interest lying behind this kind of actions, but it would be wrong to limit their understanding to self-interest. They are in line with China's general responsible attitude in the international relations - from the adoption at home of the painful "one child policy", to its standing in the major crisis worldwide, China shows indeed responsibility to the Planet. Starting from 2003, this responsible attitude is reflected in the environmental field as well, even though more timid in the beginning. The Chinese government and public have gone through a gradual process of recognition of the relationship between development and environmental protection. The Chinese government has put forward a series of new development concepts, development goals and guiding principles, centered around the "three transformations" emphasized by Premier Wen Jiabao during the Sixth National Conference on Environmental Protection (CCICED, 2006). ${ }^{5}$

The "three transformations" represent the new strategic approach to environmental problems, which manifests in the "continuous exploration of the new alternative environment and development path that will help China relieve the massive resource and environmental pressures it would face, should it stay with the conventional economic growth mode" (CCICED, 2006). The subsequent legal and administrative steps are numerous, confirming the country's leadership determination for stronger stance in the matter. Although most of the Western and Chinese authors admit that the results are still limited, due to poor implementation, abundance of overlapping norms, opposition of local governments or citizens' lack of knowledge regarding avenues for redress, the debate raised the level of public awareness to the point that China scores very high in international surveys on this topic (see for example Greendex, 2012). ${ }^{6}$ The question that remains, as far as this paper is concerned, is where the business stands, the managers more precisely, in this promising set-up.

There is no doubt on the depth and sincerity of the rulers' commitment towards new paths of sustainable development, and most authors agree that China's environmental legal framework is relatively complete, broad in coverage, and comprehensive (Lee, 2008, citing Sitaraman, 2007), and the environmental situation is already slightly improving. However, the influence on the overseas investors of this radical change of attitude towards the relation between growth and environment is less evident. There is indeed an improvement in the environmental

\footnotetext{
${ }^{5}$ The first transformation concerns the change from economy-centered development to equal attention on both environmental protection and economic development. The second is the change from delayed environmental protection after economic development to simultaneous environmental protection and economic development. The third is the change from sole administrative measures to an integrated approach of legal, economic, technical and necessary administrative measures.

${ }^{6} 72$ percent of consumers agreed with being very concerned about environmental problems.
} 
attitude of the Chinese TNCs lately, and it may be in part attributable to measures generated by the new orientation at the top-especially the restrictions in financing may have had a role.

Other than that, improvements in the environmental regime in the home country have in general little impact on the overseas investors, unless they are specifically targeted to extraterritorial aims. The new ethical approach towards ecology of the Chinese rulers does not necessarily need to be shared by an expat manager of a big Chinese TNC investing in Latin America or Africa and facing fierce competition from Western companies; the pressure of winning a contract, maximizing the profit, or even the inertial application of the principle that was valid until recently in China- " pollute first, control later"-may be stronger than some remote signals that at home, the country switched to ecological modernization. Besides, there is an ethic in serving your country to the best you can, and since most of the big Chinese companies investing abroad are SOEs, economical performance may count more as ethical behavior for a patriotic manager, than obeying the new principles of environmental behavior.

Having moved the discussion on ethics to the manager level—-the person(s) on whose hands the strategic and tactical operational decisions lie in regards to all operations abroad, including those with impact on environment -a quick reference to the culturalist debate is inevitable. We have noted the responsible ethical international behavior of China at political levels, but a country, unlike a person, can become responsible over night, through a radical shift of policies and norms. The person's ethic instead is more resilient, conditioned by stable and persistent traditional cultural values, even though occasionally altered by the potential impact of changes in social, political, and economic environments (Shafer, 2007). As far as Chinese managers are concerned, the traditional values seem to refer to innate cultural characteristics such as hard work, thrift, trust, patience, reliance upon kin and relations, security avoidance complex and the accumulation of family wealth, these and other traits being operationalized in distinctive business practices characterized by highly centralized decision-making structures and processes and loose formal organizational structures, roles or written procedures (Redding, 1990).

However, when it comes to the impact of political changes on the manager's traditional values, the picture becomes darker: there seems to be unanimity among Western and Chinese scholars alike, and even among Chinese leadership (Harvey, 1999), ${ }^{7}$ that the impact on management's ethics of the changes initiated in 1979 was devastating. While providing the growth benefits and improvement of the material conditions of the people in general, and altogether leading to the country's modernization and accession to a remarkable international status in all regards, the asymmetric development ${ }^{8}$ left room for the emergence of a variety of issues in business ethics - corruption, abuse of environment, stock market manipulation, tax cheating, fraudulent dealings, all manners of plundering of state assets etc (Tam, 2002).

In little more than half century, China experienced first a thorough denunciation of Confucianism, then an overturn of Maoist values, so it is of no surprise that the value system of the Chinese people has gone through a continual process of remaking (Whitcomb, 1998). Things can change however, and thousands of years of worshiping acceptance, benevolence, selflessness and honesty will in the end matter more than few decades of worshipping money. One author salutes the resurrection of an old Chinese ingredient: harmony as a way to solve a broad range of conflicts is resurfacing (Fung, 2006). The old concept was made the foundational principle of Chinese foreign policy, but in Fung's book is seen as the solution more broadly for resisting the massed assaults on Chinese traditional values and way of life by material incentives and western cultural influence.

For the particular case of the environmental values, the author notes that as a whole, the East Asian culture is more reserved, less prompt to challenge nature; hence, one may assume that the wrongdoings by Chinese TNCs in the host countries will decrease, by a normal process of reconnection to old traditions. But for reasons emphasized in the previous section, the country's leadership cannot afford the luxury to wait until the reverberations of the call for ecologization and ethics will change managers' mentality.

The general problems of TNCs' lack of accountability for environmental wrongdoing may or may not be aggravated, in the Chinese TNCs case, by particular factors like the ethics of serving the people, in a socialist market economy, or by the temporary alteration of values due to the global shock. In the end, what counts that the country's leadership has the means, the motivation and the ethical base to address a problem common for all humanity.

\footnotetext{
${ }^{7}$ The Chinese official interviewed was concerned that traditional Confucian notions of commercial ethics, which were long-established in "old China", had seriously deteriorated as a result of market reforms.

${ }^{8}$ For example, the "crevasses" left in the legal system, due to its quick adaptation to the new realities.
} 


\section{Conclusion}

This article was built around the notions of opportunity and necessity. Combined, the two could push China to an unexpected position of world leader in a field where preconceived ideas and its own past actions have reserved it a laggard position. The country's leadership has the means, the motivation and the ethical base to address an international problem debated for decades. A cost-benefit analysis by Chinese policy makers may indicate that action should indeed be taken, in spite of some short term economic disadvantages; for this event, our article attempted turning the spotlight towards the "pro-action" variables, especially motivation.

We are perfectly aware that the Chinese overseas investors win contracts, among other reasons, by keeping the environmental standards, at a maximum, at the level required by the host country, ${ }^{9}$ which is known as often inadequate; any toughening of the game rules will damage their corporations' chances in the global competition. Even so, for the case some policy maker will want to put all the "pros" and "cons" of extraterritorial regulatory action in balance, this article listed the "pros".

Had we chosen a more dramatic tone, explaining this article's logical thread would have started with a description of the unprecedented global environmental destruction, quoting maybe the MIT Report 2030, published in 2012; seemingly, the planet and the humankind will fall in a deep crisis in less than two decades. Since we do not believe in the power of "we need to act before it's too late" slogan to ignite action, we chose instead a more utilitarian strategy: it is the moment to re-think the possibilities of disciplining the TNCs by their home countries not because the planet collapses, but because we have new actors-the emerging economies—with different political and economical cultures, different institutional and corporate mechanisms and different global interests.

When the United Stated adopted the Foreign Corrupt Practices Act in 1977, it seemed suicidal in view of its overseas investors' performance; yet the measure, seen by some as a confirmation of self-regulatory regime's failure, was in the end adopted by the majority of the capital exporters - even by China, see the recent (2011) modifications of the Criminal law to include criminalization of bribing a foreign official.

China has the opportunity and motivations to do exactly the same thing in regard to its overseas investors' environmental behaviour, and this article attempted to stimulate thoughts on this matter in Beijing. Going back to the balance mentioned few lines above, we want to remind that the huge losses encountered recently by China in Myanmar, due to Myitsone's Dam project abandonment (Sun, 2012), suggest that reputation and economic aspects may well stay on the same side of the balance.

\section{Acknowledgements}

This paper is supported by China Institute for WTO Studies, UIBE (132XWT001).

\section{References}

Alden, C. (2007). China in Africa. London: Zed Books.

Anderson, J.R. (1983). A Spreading Activation Theory of Memory. Journal of Verbal Learning and Verbal Behavior, 22, 261-295. http://dx.doi.org/10.1016/S0022-5371(83)90201-3

Cavusgil, T., et al. (2004). The Framework of a Global Company: A Conceptualization and Preliminary Validation. Industrial Marketing Management, 33, 711-716. http://dx.doi.org/10.1016/j.indmarman.2003.01.001

China Council for International Cooperation on Environment and Development-CCICED (2006). Annual Policy Recommendations. http://www.cciced.net/encciced/policyresearch/recommendations/201205/t20120515_228483.html .

CJA-The Center for Justice and Accountability (2013). Overview of the Case Kiobel. http://cja.org/section.php?id=510

Cravens, K., et al. (2003). The Reputation Index: Measuring and Managing Corporate Reputation. European Management Journal, 21, 201-212. http://dx.doi.org/10.1016/S0263-2373(03)00015-X

Dowling, G. R. (2004). Corporate Reputations: Should You Compete on Yours? California Management Review, 46, 19-36. http://dx.doi.org/10.2307/41166219

Etzion, D. (2007). Research on Organizations and the Natural Environment, 1992-Present: A Review. Journal of Management, 33, 637-664. http://dx.doi.org/10.1177/0149206307302553

Falkner, R. (2005). American Hegemony and the Global Environment. International Studies Review, 7, 585-599. http://dx.doi.org/10.1111/j.1468-2486.2005.00534.x

${ }^{9}$ Which explains why the GEP 2013, in a total of 1400 words, uses the syntagm "host country" for 14 times. 
Fombrun, C. (1996). Reputation: Realizing Value from the Corporate Image. Boston, MA: Harvard Business School Press.

Fung, F. C. V. (2006). China's Harmony Renaissance: What the World Must Know. San Francisco, CA: World Harmony Organization.

Global Intelligence Alliance (2011). Business Perspectives on Emerging Markets 2012-2017 http://www.globalintelligence.com/insights-analysis/emerging-markets

Greendex Research on Consumer Behaviour (2012). Survey of BRIC Countries Green Consumers. http://www.globalsherpa.org/green-consumer-research-sustainable-consumption

Gugler, P., \& Shi, J. Y. J. (2009). Corporate Social Responsibility for Developing Country Multinational Corporations: Lost War in Pertaining Global Competitiveness? Journal of Business Ethics, 87, 3-24.

http://dx.doi.org/10.1007/s10551-008-9801-5

Harvey, B. (1999) “Graceful Merchants”: A Contemporary View of Chinese Business Ethics. Journal of Business Ethics, 20, 85-92. http://dx.doi.org/10.1023/A:1005795117923

Hoskisson, R. E., et al. (2000). Strategy in Emerging Economies. Academy of Management Journal, 43, 249-257. http://dx.doi.org/10.2307/1556394

Hu, T. (2013). A Look at China's New Environmental Guidelines on Overseas Investments (post on the WRI website) http://www.wri.org/blog/look-chinas-new-environmental-guidelines-overseas-investments

Hurell, A. (2006). Hegemony, Liberalism and Global Order: What Space for Would-Be Great Powers? International Affairs 82, 1-19. http://dx.doi.org/10.1111/j.1468-2346.2006.00512.x

Keleman, D. and Vogel, D. (2010). Trading Places: The Role of the US and EU in International Environmental Politics. Comparative Political Studies, 43, 427-456. http://dx.doi.org/10.1177/0010414009355265

Kirshner, J.A. (2012). Why is the U.S. Abdicating the Policing of Multinational Corporations to Europe? Extraterritoriality, Sovereignty, and the Alien Tort Statute. Berkeley Journal of International Law, 30, 259-302.

Kotschwar, B. et al. (2012). Do Chinese Mining Companies Exploit More? http://www.americasquarterly.org/do-chinese-mining-companies-exploit-more

Lee, C. J. (2008). “Pollute First, Control Later” No More: Combating Environmental Degradation In China through an Approach Based In Public Interest Litigation And Public Participation. Pacific Rim Law \& Policy Journal, 17, 795-823.

Lopez, C., Gotsi, M., \& Andriopoulos, C. (2011). Conceptualizing the Influence of Corporate Image on Country Image. European Journal of Marketing, 45, 1601-1641. http://dx.doi.org/10.1108/03090561111167315

Mol, A. P. J. (2011). China’s Ascent and Africa’s Environment. Global Environmental Change, 21, 785-794. http://dx.doi.org/10.1016/j.gloenvcha.2011.03.015

Pegg, S. (2012). Social Responsibility and Resource Extraction: Are Chinese Oil Companies Different? Resources Policy, 37, 160-167. http://dx.doi.org/10.1016/j.resourpol.2011.01.002

Redding, G. (1990). The Spirit of Chinese Capitalism. New York: De Gruyter.

REPRISK (2010). Global Business Intelligence on Environmental, Social and Governance (ESG) Risks. http://www.reprisk.com/downloads/mccreports/23/150312\%20Top\%2010\%20Most\%20Controversial\%20Mining\%20Co mpanies_RepRisk.pdf

Rocio, G., \& Yagenova, S. (2009). Indigenous People’s Struggles against Transnational Mining Companies in Guatemala: The Sipakapa People vs GoldCorp Mining Company. Socialism and Democracy, 23, 157-166. http://dx.doi.org/10.1080/08854300903208795

Shafer, W.E., Fukukawa, K., \& Lee, G. M. (2007). Values and the Perceived Importance of Ethics and Social Responsibility: The U.S. versus China. Journal of Business Ethics, 70, 265-284. http://dx.doi.org/10.1007/s10551-006-9110-9

Shinsato, A. (2005). Increasing the Accountability of Transnational Corporations for Environmental Harms: The Petroleum Industry in Nigeria. Northwestern Journal of International Human Rights, 4, 186-209.

Spring, K. (2011). The Real Cost of Gold in Honduras: Goldcorp and Honduras Regime Cover-Up Blood and Urine Testing and Poisoning at San Martin Mine. Rights Action Report.

http://resistenciahonduras.net/index.php?option=com content\&view=article\&id=2817:the-real-cost-of-gold-in-honduras\& catid=98:opinions\&Itemid=347

Tam, O. K. (2002). Ethical Issues in the Evolution of Corporate Governance in China. Journal of Business Ethics, 37, 303-320. http://dx.doi.org/10.1023/A:1015297216723

Todd, G., \& Webber, J. (2008). Imperialism and Resistance: Canadian Mining Companies in Latin America. Third World Quarterly, 29, 63-87. http://dx.doi.org/10.1080/01436590701726509

Sitaraman, S. (2007). Regulating the Belching Dragon: Rule of Law, Politics of Enforcement, and Pollution Prevention in Post-Mao Industrial China. Colorado Journal of International Environmental Law and Policy, 18, 52-80. 
Sun , Y. (2012). China and the Changing Myanmar. Journal of Current Southeast Asian Affairs, 31, 51-77.

UNHCR (2008). Climate Change, Natural Disasters and Human Displacement: A UNCHR Perspective. http://www.unhcr.org/refworld/type,RESEARCH,UNHCR,,492bb6b92,0.html

Wallerstein, I. (1974). The Modern World-System. Waltham, MA: Academic Press.

Wang, H. (2003). National Image Building and Chinese Foreign Policy. China: An International Journal, 1, 46-72.

Whitcomb, L., Erdener, C., \& Li, C. (1998). Business Ethical Values in China and the U.S. Journal of Business Ethics, 17, 839-852. http://dx.doi.org/10.1023/A:1005793424492

World Economic Forum (2012). Emerging Best Practices of Chinese Globalizers.

http://www3.weforum.org/docs/WEF_EmergingBestPracticesChineseGlobalizers_IndustryAgenda_2012.pdf 